\title{
ANALYSIS OF STUDENTS' LEVEL OF MATHEMATICAL UNDERSTANDING THROUGH ONLINE LEARNING ON BINOMIAL OPPORTUNITY DISTRIBUTION MATERIALS
}

\author{
Rifka Usman ${ }^{1}$, Gusniwati ${ }^{2}$, Herlan Sanjaya ${ }^{3}$ \\ State Islamic Institut of Parepare, INDONESIA
}

ARTICLE'S

INFORMATION

\section{Article history:}

Received: Dec-04-2020

Accepted: Dec-27-2020

Keywords: Understanding, Learners, Online learning

\section{Corresponding address:}

Rifka Usman, E-mail:rifkausman@iainpare.ac.id

\section{INTRODUCTION}

Mathematical understanding translated from the term mathematical understanding is a very important mathematical ability that students must have in learning mathematics. Rational importance of the ownership of mathematical comprehension ability among others is the ability is listed in the objectives of mathematics [1] [2] and in the NCTM [3]. The statement is in accordance with the opinion of Hudoyo [4] which states: "The purpose of teaching mathematics is so that the knowledge conveyed can be understood by learners". A good education is a successful effort to bring students to the goal to be achieved, namely so that the materials delivered are fully understood by the students.

Mathematical understanding is and the purpose of a mathematical learning process. Mathematical understanding as a goal, means an ability to understand concepts, distinguish a number of separate concepts, and the ability to perform meaningful calculations on situations or broader problems. So that the ability of mathematical understanding is a strength that must be considered and treated functionally in the process and objectives of mathematics learning, especially the sense of obtaining mathematical understanding at the time of learning, it can only be done through learning with understanding [5].

Skemp [6] states that understanding there are two types, namely instrumental understanding and relational understanding. Instrumental understanding of a mathematical concept means an understanding of distinguishing a number of concepts as understanding concepts that are mutually separated and only memorize formulas with simple calculations. While relational understanding means being able to perform meaningful calculations on broader issues. Based on the explanation 
above, it can be concluded that the understanding of the mathematical concept of the learner is the ability of the learner in finding and explaining, translating, interpreting, and concluding a mathematical concept based on the formation of his own knowledge, not just memorization.

The importance of understanding ownership by students is also stated by Santrock [4] that understanding concepts is a key aspect of learning. Similarly, mathematical understanding is an important foundation for thinking in solving math problems as well as real-life problems. In addition, mathematical comprehension ability is very supportive in the development of other mathematical abilities, namely communication, problem solving, reasoning, connection, representation, critical thinking and mathematical creative thinking as well as other mathematical abilities. Similar opinions are expressed by Wiharno [4] that mathematical comprehension skills are a strength that must be considered during the mathematical learning process, especially to gain meaningful mathematical knowledge.

Students can understand the material well when trying to learn first. Learning before being taught can improve understanding of the material to be studied [7]. Although there are still uncomprehensible materials in the classroom, students can ask the teacher when explaining the material, so that the level of students' understanding of the material is better. Students should not be restricted from one source book in learning the material [8]. Students are also directed to find concepts from other sources or media on the internet in order for their understanding of the concept to develop.

Mathematics or previously called the science of reckoning is a science that studies magnitude, structure, space, and change. Seeing the importance of mathematics in life so that mathematics is studied at all levels of education in Indonesia. "The field of mathematical study is necessary for the calculation process and thought process that people desperately need in solving various problems" [9]. Therefore, mathematics becomes the most important subject for everyone to master from young children to adults.

However, not a few learners consider maths one of the difficult subjects because it requires understanding of complex concepts and calculations. Thus, the learner does not like this lesson and ultimately has an impact on his or her low level of cognitive understanding. Therefore, various ways are done by the government or teachers so that mathematics subjects can attract students. One of them is by revising the existing curriculum.

In the 2013 curriculum, the purpose of mathematics learning is to have factual and conceptual abilities in knowledge [10]. However, the world is currently experiencing Covid-19 outbreak and one of the countries that is feeling the impact is Indonesia. Since the beginning of March 2020, Covid-19 cases continue to grow so that the government closes all activities that trigger new cases, or in other words Large-Scale Social Restrictions. This certainly has an impact on all areas, especially in the field of education, which requires schools to be closed and the learning process adjusts to the conditions.

The meaning of learning in The Great Dictionary of Indonesian Language, is the process, the way the deeds make people or living things learn. Furthermore, learning is an activity aimed at teaching learners [11]. Law of the Republic of Indonesia Number 20 year 2003 concerning the National Education System, stated that learning is the process of interaction of learners with educators and learning resources in a learning environment. Every teacher is important to understand the learning system, because with the understanding of this system, each teacher will understand about the learning objectives or expected results, the process of learning activities that must be done, the utilization of each component in the process of activities to achieve the 
objectives to be achieved and how to know the success of the achievement.

The purpose of learning is the ability (competency) or skill that is expected to be possessed by learners after they have done a certain learning process. Wina Sanjaya suggested that the formulation of learning objectives must contain elements of ABCD, namely Audience (who should have ability), Behaviour (behavior that is expected to be possessed), Condition (in conditions and situations where the subject can show ability as a result of learning that he has obtained), and Degree (quality or quantity of behavior that is expected to be achieved as a minimum limit) [11].

The learning process that is usually done face-to-face turns into an online learning process or often called learning from home to reduce the rate of Covid-19 increase in Indonesia. Based on the policy of the Ministry of Education on Emergency Curriculum in the Unit of Education in Special Conditions "The curriculum in the education unit in special conditions provides flexibility for schools to choose a curriculum that suits the learning needs of learners".

The process of learning mathematics can be done in two ways, namely conversional learning and online learning. Conversional learning is a face-to-face or face-to-face learning in the classroom. With this kind of learning, the participation and activeness of learners is expected, but in fact with this method is still not optimal. While the process of online learning is a learning that is done using technology-based, such as computers, mobile phones, laptops and others.

Online learning is one of the learning methods that use the internet network [12]. In line with the opinions according to Bilfaqih and Qomarudin which suggests that online learning is a learning that is done through the web network with each subject providing material in the form of video recordings or slideshows and tasks that must be done within the specified time limit [13]. So online learning is a learning effort carried out by teachers and learners but using a web network.

Online learning (also known as online learning, or e-Learning) is the result of a learning delivered electronically using computers and computer-based media. The material is often accessed through a network. E-learning is also a very useful source of online information because elearning learning doesn't have to be face-to-face [14]. So from some opinions above online learning. So, from some of the descriptions above learning from is one of the learning methods based on technology.

The learning process is done online with regard to the objectives of mathematics learning. Where, the purpose of Mathematics learning is to develop the ability to solve mathematical problems of learners [15]. While the purpose in mathematics learning in the 21st century known by the characteristics of 4C is Communication, Collaboration, Critical Thinking and Problem Solving, Creativity and Innovation. In mathematics, problem solving is a very important part of the math curriculum because in the process of learning and solving, learners use their knowledge and skills to apply to problem solving [16].

Based on the description above, the problem formulation in this article is how the level of understanding of the mathematical concepts of learners in the material distribution of binomial opportunities in online learning in SMAN 10 PINRANG.

\section{METHODS}

This research method uses descriptive qualitative research method. Arikunto (2010) descriptive research is a study that aims to find out the circumstances and conditions in which the results are described in the form of research reports. The subjects of this study were students of grade XII SMAN 10 Pinrang. The instrument used in this research is a problem solving ability test consisting of 3 points of description and interview. The data obtained is then analyzed using 
qualitative data analysis.

\section{RESULTS AND DISCUSSION}

Based on the test results that have been done in class XII IPA SMAN 10 Pinrang conducted online using Microsoft Teams and WhatsApp with Binomial Opportunity Distribution material. Based on indicators of problem solving capability stages as well as scoring guidelines that have been created.

Table 1. Achievement of Mathematical Comprehension Skills

\begin{tabular}{|c|c|c|}
\hline No. & Student Name & Score \\
\hline 1. & Asriani & 95 \\
\hline 2. & Nurul Amelia & 80 \\
\hline 3. & Nursyafatma & 100 \\
\hline 4. & Nuradha & 80 \\
\hline 5. & Alifia Maritza & 80 \\
\hline 6. & Mutmainna & 100 \\
\hline 7. & Fatma Mauldya & 80 \\
\hline 8. & Megawati & 80 \\
\hline 9. & Fitriyani & 100 \\
\hline 10. & Nur Indah & 95 \\
\hline 11. & Nurhalima Amri & 95 \\
\hline 12. & Rezky Amelia & 95 \\
\hline 13 & Siti Fatimah & 95 \\
\hline 14. & Nadia & 80 \\
\hline 15. & Fikrandi & 95 \\
\hline 16. & Hariyati & 80 \\
\hline 17. & Anawilana & 80 \\
\hline 18. & Nuraeni Akib & 80 \\
\hline 19. & Nurul Izzah & 95 \\
\hline 20. & Arafah & 100 \\
\hline 21. & Muh Nasrum & 95 \\
\hline 22. & Asma Ulhuna & 95 \\
\hline 23. & Muammar & 100 \\
\hline 24. & Aswanda & 95 \\
\hline 25. & Alfi Khaeria & 90 \\
\hline 26. & Nurul Syakirah & 90 \\
\hline 27. & Fitria Ramadhani & 95 \\
\hline 28. & Arif Sandy Syahrir & 80 \\
\hline 29. & Miftahul Jannah & 80 \\
\hline
\end{tabular}

Based on the evaluation results contained in table 1, it can be seen that the ability of learners to be able to utilize, choose and use the formulas and calculations shown in the question is $81 \%$. This indicates that overall to achieve such indicators has been achieved. Evidenced from the evaluation results where 11 people who got a score of 80,2 people who got a score of 90,9 people who obtained a score of 95 and 5 people obtained a score of 100.

\section{CONCLUSIONS AND SUGGESTIONS}

Based on the results of data analysis that the level of mathematical understanding of students in grade XII IPA SMAN 10 Pinrang on Binomial Opportunity Distribution material through online learning using Ms. Teams and WhatsApp applications can be concluded that there are 11 people get a score of 80, 2 people get a score of 90, 9 people who get a score of 95 and 5 people get a score of 100. The overall average is 75.27 . This indicates that the level of mathematical understanding of learners is able to choose, use precise formulas and calculations. 


\section{THANK-YOU NOTE}

There is no word that deserves to be said other than gratitude for the presence of Allah SWT, Blessings of abundance and mercy of the compiler is able to finish the writing entitled "Analysis of The Level of Mathematical Understanding of Learners through Online Learning on Binomial Opportunity Distribution Material" well.

The author realizes that in the process of writing this Scientific Work many obstacles. But thanks to Allah SWT and assistance from various parties so that the obstacles faced can be overcome. On this happy occasion, not forgetting the author thanked all parties who have provided guidance, direction, advice and thoughts in this writing, especially to both my parents, Mrs. Gusniwati and Mr. Herlan Sanjaya As Supervisors, Mrs. Supriani As Teacher Pamong At SMAN 10 Pinrang and Special for Sister Hardianti Mustakim And friends who have helped.

\section{REFERENCE}

[1] Depdiknas, "Pedoman Khusus Pengembangan Sistem Penilaian Berbasis Kompetensi SMP," Jakarta, 2006.

[2] Kemendikbud, “Kerangka Dasar dan Struktur Kurikulum 2013,” Jakarta, 2013.

[3] National Council of Teachers of Mathematics, "Curriculum and Evaluation Standards for School Mathematics," Reston, VA, 1989.

[4] H. Hendriana, E. E. Rohaeti, and U. Sumarmo, Hard Skills dan Soft Skills Matematika Siswa. Bandung: Refika Aditama, 2017.

[5] L. L. Syarifah, "ANALISIS KEMAMPUAN PEMAHAMAN MATEMATIS PADA MATA KUliah PEMbelajaran MATEMAtiKa SMA II," J. Penelit. dan Pembelajaran Mat., 2017.

[6] U. Sumarmo, "Kemampuan Pemahaman dan Penalaran Matematika Siswa SMA Dikaitkan dengan Kemampuan Penalaran Logik Siswa dan Beberapa Unsur Proses Belajar-Mengajar," 1987.

[7] H. D. Putra and R. Purwasih, "Meningkatkan Prestasi Belajar dan Keaktifan Mahasiswa Melalui Project Based Learning," P2M STKIP Siliwangi, vol. 2, no. 2, pp. 128-136, 2015.

[8] H. D. Putra, "Pengaruh Project Based Learning Terhadap Kemandirian Belajar Mahasiswa," in Prosiding Seminar Pendidikan Nusantara 2016, 2016, pp. 106-115.

[9] A. Susanto, Teori Belajar dan Pembelajaran di Sekolah Dasar. Jakarta: Kencana Prenamedia Group, 2014.

[10] E. Unaenah and M. S. Sumantri, "Analisis Pemahaman Konsep Matematis Siswa Kelas 5 Sekolah Dasar pada Materi Pecahan,” J. Basicedu, vol. 3, no. 1, pp. 106-111, 2019.

[11] W. Sanjaya, Strategi Pembelajaran Berorientasi Standar Proses Pendidikan. Jakarta: Kencana Prenamedia Group, 2008.

[12] M. I. Mustofa, M. Chodzirin, and L. Sayekti, "Formulasi Model Perkuliahan Daring Sebagai Upaya Menekan Disparitas Kualitas Perguruan Tinggi (Studi terhadap Website pditt.belajar.kemdikbud.go.id)," W alisongo J. Inf. Technol., vol. 1, no. 2, pp. 151-160, 2019.

[13] Y. Bilfaqih and M. N. Qomarudin, Esensi Pengembangan Pembelajaran Daring. Yogyakarta: Deepublish, 2015.

[14] S. Lane, "Effective Online Discussion Forums as a Legal Learning Space," Am. J. Educ. Res., vol. 4, no. 5, pp. 392-396, 2016.

[15] Z. Arifin, "Mengembangkan Instrumen Pengukur Critical Thinking Skills Siswa pada 
Pembelajaran Matematika Abad 21," J. THEOREMS (The Orig. Res. Math., vol. 1, no. 2, pp. 92-100, 2017.

[16] L. Misu, "Mathematical Problem Solving of Student by Approach Behavior Learning Theory," Int. J. Educ. Res., vol. 2, no. 10, pp. 181-188, 2014.

\section{BIOGRAPHY}

\section{Rifka Usman}

Student in State Islamic Institute Parepare. Phone Number: 082278715847, E-mail: rifkausman@iainpare.ac.id

Gusniwati

Lecturer in the State Islamic Institute Parepare. She obtained her Strata-2 (S2) in Universitas Tadulako.

Herlan Sanjaya

Lecturer in the State Islamic Institute Parepare. He obtained his Strata-2 (S2) in STMIK Handayani Makassar. 